\title{
Santri's Community in Political Change: Historical Interpretive
}

\author{
${ }^{1 *}$ M. Faishal Aminuddin \\ ${ }^{1,}$ Department of Political Science, University of Brawijaya, Malang
}

\begin{abstract}
This study seeks to understanding the historical context of the construction and position of of Santri's community in Javanese society. Evidences from case study in an agrarian village in East Java proved that political change had potentially eroded the patrimonial system which embedded in this community. The analysis drawn from research findings which scattering the complexity of indigenous factors covering historical background, institutional change, cultural form and economical mode of production within society. Using morphogenetics approach coupled with ethnographical methods, this research found that patrimonial system in santri's community as traditional Islam backbone has shifted. From being a closed patron-cliental relationship, now it becomes more open and diverse. This study contributes to explain political legitimacy in Islamic-based organization in Indonesian politics after the authoritarian New Order regime. Particularly to capture what happens in the micro-level political phenomenon. This study also reveals the neglected and critical phase in Indonesia democratic transition from below.
\end{abstract}

Keywords: Santri community, patrimonialism, Javanese, political Islam

\section{Research Background}

Various studies conducted on Santri community (Santri's) in the New Order period is locating key position on the role of Kiai which regarded as the pillar that holds the role as patron who has the authority and power to control the Islamic boarding school or Pesantren (Dhofier, 1982; Ida, 1999; Bruinessen, 1994; Feillard, 1999; Fealy, 1998). In those studies, patron-client model in traditional relation not much different with traditional society where there is unequal exchange that reflects differences in status, the cult of the individual and their overall relationship indefinitely (Scott, 1972). The authority of Kiai is the implementation of the paternalistic system which not only has a

* Corresponding author: M. Faishal Aminuddin

mfaishal@ub.ac.id

Published online at

Copyright (C) 2019 PSP2M UB Publishing. All Rights Reserved positive side which act do the stint as a guardian of common value in their group. But also has a negative side because if they were not to be trusted will make the group scattered (Dhofier, 1982).

Several important studies portray how the Santri's in the period of democratic transition after New Order regime in post 1998 also generate interesting findings. Turmudi (2006), for example, shows that the relationship between the Kiai and society is governed by both understanding of Islamic doctrine. Also change the norms prevailing in society. Nonetheless, Kiai still have a political force able to mobilize their followers and influence political choices which refers to the bonds of kinship and more affiliated on 
subculture or class division based on mode of production. The main factor that could be seen to understand the basis of Santri's political legitimacy can be traced from the landmark study conducted during the New Order era; Nakamura (1983) mentions that the Islamization extends made abangan and priyayi group began to adjust the principles of Islamic teachings in daily practice and shift to a position piously.

The santrinisasi (converted process to become Santri) could ultimately be converted to mobilize political support at the political party. The function of community leaders or traditional a dominating figure in the political and social activity of society evidenced by the compliance and participation in politics according to political choices are determined by the parent or figures (Jackson, 1990). These studies trace the origin of the construction of the Santri's community including some of its constituent elements namely the political, economic systems alteration and patron-client relationship therein. Specifically, studies exist doesn't appear yet to providing explanation about the effectiveness santrinisasi at the beginning of the New Order. This article starting with the question, how the formative process of Santri's community? In the political change, if there was a shift in the system, as far as it impacts on the structure of the community institutions? Especially in relation of patronclientelism therein. This study took object of research in the Krecek village, Kediri, East Java as a representation of rural Java, with an agrarian society that have a diversity of religious organizations.

The study applied morphogenetics approach which argue that society is an open system that is given character by various influences that produce structural arrangements and cultural forms. Structural picture of a society fluctuates and depends on the desire of intrinsic properties to perform reproduction. The relationships among them reproduce various combinations constantly in reproduction (morphotasis) or transformation (morphogenesis) to produce action in the future (Archer, 1995). This study uses ethnographic research methods which had I am living in the village between 2005-2006 for 6 months. Geertz (1973) explains that ethnography emphasis on better techniques on selecting informants, text transcripts and field notes. This often named as "thick description" in which private investigators construction as the construction of others. It could also be called "seeing a subject from the point of view of the other". Ethnography model is used as part of data collection that is used as a substance of analysis.

\section{Santri's Community: Building a Conceptual Framework}

In the previous studies, Santri are understood as people who studied in the school and have Kiai as a teacher or a higher authority but also the cultural roots group of Muslims (Geertz, 1963). Santri is an articulation both sociological and anthropological while characteristics that appear in Islamic politics led to the polarization of Islamic ideology. Fox (2004) calls it as a historical phenomenon of mutual opposition dichotomy between modernists and traditionalists. The modernists group are represented by Muhammadiyah which aim to strengthen the scholarly and intellectual foundation while traditionalists are represented by $\mathrm{NU}$ that preserve pesantren education system and emphasis on Islamic law 
interpretation derived from the Shafi'i madhab.

In his study, Hefner (2000) sharpens the framework to understanding Santri. He argued that Santri as one of voluntary based organizations be potential capital as an agent of civil society and democratization to promoting civic participation. His conception saw the relationship between Islam and the state is more emphasis on the potential emergence of Muslim groups in democratization. Some institutions of Muslim groups have a capacity to mediate where citizen can build a sociopolitical environment for freedom of speech, participation and tolerance. Hefner agreed in outline view of some western scholars who studied Indonesian and found that the political elite culture had been made up of many things including the culture of Hinduism and Buddhism were dominant then affects the existence of the Islamic society (Jackson and Pye, 1978; Jay, 1963; Anderson, 1990).

In fact, as pesantren student, Santri can perform intrusion in political and social life in society through the organization and also establish an independent character as a society. Thus, I define Santri's community as an extension of a Muslim entity who transform a set of Islamic values of the pesantren institutions into society institutions. This community has three types of bases forming; 1) pesantren as a core institution. 2) the expansion of pesantren through santrinisasi, in another entity that spawned acculturative characters of Santri. This types occupy the positions as a supporting actor. 3) compromisement with other forces that is institutionalized as the state and corporations which generate significant infiltrative effect in establishing new social entities.

I have an understanding that Santri's are bounded by patrimonial relation with the reasons: dominant kinship node, the modalities of exchange amongst the actors is semi-open and the exclusive chain of hierarchy. The importance of the political clientelism system in Javanese society had could be mobilized to protect the village from the rebels, and it is the implementation of the modalities clientelism (Antlöv, 1994). Other studies found the role and dynamics of the Santri's in the New Order era, many of them support the theory that mentions the role of state in subjugation of society through various ways such as supporting the local elite, mastery through its apparatus and make grow the natural dependencies in the country (Hefner, 1976; Schiller in Budiman, eds, 1992). Actually, the explanation of patron-clientelism is not much enough to describe the complexity of relationships within the Santri's. For example, their dependency against state subsidies and protection to face the grassroots which patrimonialism works by collecting the accumulated gain.

Many facts are demonstrated in studies which looks at high level of dependence on agriculture, specifically peasant in the Javanese society which models of agricultural production cannot be separated from management aspects of irrigation canal. Intervention and involvement of the state in the management of irrigation is very likely intended to increase production yield for irrigated land area could be wider (Geertz, 1983; Kurasawa, 1993). But this intervention is not only in aid capacity in the field of construction of physical facilities such as seeking a dam or other tertiary canal but influence to the 
management model of the irrigation system. The New Order regime then restore state control of the agriculture sector through its institutions (Both and McCawley, eds, 1990). State control over sufficient rice production in order to ensure the stability of the basic needs of agriculture. Later this effort had potentially reducing the conflict volatility of the grassroots.

I emphasizing the basic concept to put the patrimonial system in Santri's relationship with Javanese society in general, to the widespread and involves a group of people with political power to producing patrimonialism models. Weber (1978) defines patrimonialism as a situation where the administrative apparatus was governed and responsible in its key leaders. The important difference that can be seen from the pattern of clientelism and patrimonialism lies in the existence of the institution. Patrimonial closely related to political control in which the institutions involved in it like a state, plays a dominant role and controlled by patterns of dependency. Although it cannot simply to be stated that patrimonialism accommodates the patterns of clientelism in state bodies. Remember the institutional constraints often too blurry when the dominant actor also have ignorance functions of rules in the institution.

In this perspective, interesting to know whether the Santri's take advantage of social and political institutions simultaneously with economic institutions. The definition of "institutions" often connotes formal and it is often distinguished by informal institution which has a sense as a rule based on the implicit understanding and being a part of the interaction that is not expressed in written documents or contain sanctions in a formal position. For example, social norms, routines and the political process. Helmke and Levitsky (eds, 2006:5), for example, defines informal institutions as the exchange of social rules, usually unwritten, that is established, communicated and enforced outside of official sanctions. This conception actually has a weakness when faced with the challenges the boundaries between formal and informal become blurred. Formal rules were weakened and led to a strengthening of informal rules but still connected with the authorities responsible for the formal rules. In a sociological study, to understand a society noteworthy aspects of the rule of informal mechanisms in the exchange process setting an authority.

The formalization of the institution during the New Order era had impacted the social institution tends deemed to have formal shape and is identical to the legitimacy granted by the state. Then do make simple against all sorts of activities from institutions outside the state who are still working and consider it as part of local conservation. As a result, many informal institutions gradually lost many of which no trace. I call this phenomenon as "boundary-blured" between formal and informality. The formalization by the state against informal institutions that have been inherent in society, it makes the institution in all categories to be a part of the political action and became justification to act as channels of political mobilization by the state. I took the perspective from Luhman (1983) which states that the informal political arena based on the actions of social integration. In a Santri's community is rarely found absolute submission to the tradition or loyalty to an individual ruler, emotions and charisma of its leader but 
the attention is directed to the rules of the state with all kinds of legal procedures. From this point, the formation of political legitimacy have an existence. Luhman offer a conceptualization of social integration (Vergemeinschaftung) adopted from thinking Jurgen Habermas where he also adopted it from Weber's conception of systemic integration (Vergesellschaftung).

The informal politics as in the rural community is being social action beyond the systemic integration. Informal political existence is more caused by an attempt to escape from the formal political sphere that has the clear shape while social interaction that is established can be taken for various purpose. Informal institutions have a softer structure within the scope of individuals and communities that are relatively less affected by the bureaucracy. This study also take opportunity to examine Luhman's perspective who saw that characteristic of modern politics is not created by regular behavior but by exceptional behavior in which each party has its own legitimacy through conflict or other vulnerabilities. I tend to understand the relationship between formal and informal as part of controlling actor or institution interests, within a given context, informality is becoming more important and dominant than formal institutions.

\section{How Santri Community Formed Its Political History}

This study seeks to understanding about small village in the inner East Java province, Indonesia. Krecek village has an area of $7.79 \mathrm{~km} 2$ with an area of rice fields $5.36 \mathrm{~km} 2$ (Monographs of village, 2004-2006). At first glance it appears that this village does not have a long history to appear to be an agricultural village with a stagnant society and fatalist. Pedestal life obtained from the technical area of agricultural land with $5.03 \mathrm{~km} 2$ and simple agricultural land area of $0.33 \mathrm{~km} 2$. In the eastern part of the village lined mountain range of Arjuna, Anjasmara and volcano Kelud. But the ash blessing when Kelud erupts, do not make this village get adequate soil fertility. Relatively large rivers located in the northern village where the flow has been opened since the Dutch colonial period. Administratively, the village is located in the regency (Kabupaten) of Kediri and became the most northern part of the Pare districts (Kecamatan) directly adjacent districts of Ngoro in Jombang regency. The distance from the town of Pare as far as $6.6 \mathrm{~km}$ and $30 \mathrm{~km}$ from the town of Kediri. While the town of Jombang far as $25 \mathrm{Km}$. The village is classified as backward village compared to other villages in Pare that any such assistance is to be disbursed to various infrastructure development (CBS, 2006). The village consists of eight hamlets (dusun) namely: Krecek, Nepen, Karangnongko, Bumirejo, Pulorejo, Sumber Agung, Mulyorejo and Balongmanyar.

The origin and history of the village has many versions. This difference gives the message that the existence of the village is the fruit of the less successful integration. Before Indonesian independence in 1945, the village now is a region of three different villages, namely the village of Blaru which has long historical roots of Islam, Badas village carriages which was inhabited by adherents of Kejawen and Majapabitan then Ndelik village that is almost similar to the carriages. After independence, the administrative parts of three villages merged into one village (Interview Collective, 18 December 
2006). Even mazy, the actual version history of the village's most widely accepted is the role of Mbah Srandil which brought some form of krecek or a type of rice that is dried (karak) while opening of rural areas. Nonetheless, Srandil gradually become a fairy tale for penetration carried out by Islamic groups that take people away from the influences of heresy. The former of Srandil which was originally located in the hamlet of Krecek is not preserved because it was not considered as "pepunden" (tombstone) of village.

In the Dutch colonial era, the region has sugar cane plantations cultivated by HVA-the Dutch-owned company- and became part of the history of social and political developments in Pare district. They build housing and transportation and made Pare as a medium-sized city and a haven from traveling between Malang and Surakarta. Hospitals and houses built for European nationality officials with various facilities. The expansion sugar trade made Krecek became one of the sugar cane plantations that are managed by HVA and all agricultural land previously cultivated by citizens then closed and replace as plantations. The agricultural area produces rice, corn and a small portion of sugar cane and nuts. Agriculture and lake-fisheries are also dependent on supplies from the natural spring water sources exist and reopened again after sugar cane plantations being closed. In addition, there are irrigation canals built in the beginning of the New Order.

The industrial sector was operating with the opening of sacks of rosella plant. In this area, the sisal as raw material of rosella sack, can grow. Sisal is also one of the commodities that were planted when HVA operating. At the time of its inception in 1970, is able to absorb the labor force of Krecek about 700 productive workforce and sisal plantations. Office of colonial sugar cane plantations in the final year of the 1960 s functioned as rosella processing plant for the production of sacks financed by foreign investment from Japan run by a businessman of Chinese descent. But by the 1980s, the company went bankrupt and closed and made a lot of manpower switched professions to become farmers and nomads. A small portion of them set up a domestic industry, which primarily makes the fish as a commodity, is also a bit of furniture and other small-scale industries (Interview Krisbanu, 17 December 2006).

Existing hamlets also have different history. Nepen hamlets, Sumberagung and Krecek has a long history ranging from ownership of land, reorganization of the structure of society and the dynamics of Santri's which had produced more religious face. Other villages have the burden of history as a base Indonesian Communist Party (Partai Komunis Indonesia, PKI) that cannot escape from the beliefs of Hinduism in Java and political consciousness pattern that derived from a model called Majapahitan (Interview Krisbanu, 2006). Center of sugarcane plantations during the Dutch colonial is located in the village of Bumirejo and Mulyorejo. After colonial gone, the land is owned by Indonesian State-Owned enterprise for plantation (PTPN). They reopening access to water and closing the sugar cane plantations replaced by farmland. In the two villages there is a small water channel that only filled up when the rainy season but there is also draining water from other irrigation canal where every season, discharge water flows in accordance with the needs of the existing land. This explains why 
the propaganda of PKI quite successful since most people work in the sugar cane plantation sector that is relatively easy organized.

The events of 1965 became a milestone point of santrinisasi involving Islamic organizations outside NU like Muhammadiyah, LDII and 'jama'ah' congregation. For the older generation who witnessed the incident, NU is not only be a cultural force but also confirmed through political power. Kiai plays an important role as a regulator of social and political order. However, in such a position, they do not necessarily get the benefits from the state. Likewise, affiliation to political party after NU Party fuse with PPP. Santrinisasi had work with the pressure of Islamic group and the state support within their apparatus, including the bureaucracy and the military. Another exponent involved is an entity of 'priyayi' that is affiliated with Indonesian National Party (Partai Nasional Indonesia, PNI). They encourage people who are affiliated with the PKI and its wings organs to involves in the Santri's agenda. This process can also be called "sanctification identity". The incident has left a void elite position for a while. Only in the late $1960 \mathrm{~s}$, rotation or change of position of the elite did. The religious leaders into an elite along landlords with hajj (Haji) backgrounds control the land back after the land reform policy.

In the early period of the New Order regime, there was being political reorganizing to accommodate the elements of the old politics. In this time, the state entering through apparatus and different agents who are in the lower level to carry out government policies. NU's elite had not strength support to the state. Thus, the state reiterated its dependence to the forces of village bureaucracy of where many of its officers are a group of 'priyayi' while simultaneously accommodate the power of 'abangan' that previously experienced santrinisasi. For grassroots groups, the New Order period provides an opportunity to identify themselves. Mainly after infiltrating 'kejawen' groups in the circle of Golkar. From the cultural side, they are more braves to show their old belief and multiple node network that is built with the bureaucracy of the village. Organizations that close to state as LDII instead show its moderate side. Unlike the prototype of LDII in other place is often seen as puritan organization. Although santrinisasi had produce paradoxical but claims that was given by NU that its side has saved a lot of grass-roots and invites them to become followers.

Santrinisasi experiencing success because the religious elites provide a safe space for ex-PKI and nursed them in routine Islamic study that simultaneously presented in each hamlet. Until the late 1970s, it was not go smoothly because of emerging conflicts among Islamic organizations themselves. At first conflict arises between NU and LDII that is triggered by maneuvering of LDII burning yellow book (kitab kuning), damaging the mosque drum and branded NU as infidels. Conflicts never exploded into physical violence and began to decline with a family approach. The conflict caused a weakening of the consolidation of the power of civil society groups and cohesiveness among Islamic organizations. In a weak condition, the state started to occupied and took tightens control.

Main tendencies of the Islamic movement have an impact on the blurred process. Its object is santrinisasi of abangan group and this phenomenon 
raises the process involving the "indigenization" and contextualization (Woodward, 1989, 1994 Pranowo, Ricklefs 1998). In a certain extent, it could be a group of abangan indeed have experienced and santrinisasi run effectively when the symbol carried by abangan group is no longer visible. Many scholars argue that political situation change that marked in the process was a conflict in 1965 which the strength of Santri's involved in a situation uncontrolled to eliminate the role of PKI. The campaign had committed by the military which is most likely done voluntarily by the Santri, made the tragedy of the murder is happened. Not only political institution of PKI but the whole institution and its supporters (Anderson \& McVey, 1965; Nordholt, 1987; Cribb, 1990; Robinson, 1995).

There are two narrative history of the village are: the dominance of santrinisasi post-1965 and 'negaranisasi' means society institution occupied by state- which lasted from the 1970s until the late 1990s. Two of these processes resulted at least three important things that serve as antecedent factors to analyze the extent of the impact of these two processes on the model of response and Santri's resistance against social and political change. First, santrinisasi had accommodate horizontal integration model where cultural elements considered not to be a representation of political power. Even there was intervention by the state through their apparatus but it only gives impact on the polarization of administrative functions. Between strengthening the administrative structure of village government support of the state held by 'priyayi' and administrative intervention of the central government through official institutions which acquired informal institutions. These findings clarify the theory of the blurred process of the political grouping laid by Geertz, called "santrinisasi abangan" and "santrinisasi priyayi". In Krecek, through social forums driven by $\mathrm{NU}$, the group of abangan feeling safe in the santri's community without losing its identity.

Second, the transition from cultural form of 'santrinisasi' to 'negaranisasi'. In this period, there is a shifting from the cultural integration process to politics which the sociocultural cleavage had stagnated and social interaction of citizens is contaminated by political interests. As a result, there was a de-bureaucratization of the structures and institutions that involve all levels of social and economic elites. Third, negaranisasi which took place in the 1970's supported by the village bureaucracy that had been prepared as a state partner in the past. This negaranisasi models is different from the state occupy that assume there is still persistence the social institutions, cultural and even political society fully in control of the state apparatus. Negaranisasi understood as the inclusion of elements of both state institutions, agencies, apparatus, laws and norms of state at the national level to the structures and institutions of rural communities that have previously been established.

\section{Post New Order Political Change}

\subsection{Political Economy Aspect: Informal Institutions and Wage System}

After the collapse of the New Order in 1998, wind of democratization affected socio-economic structural changes. Waning dominance of the state is accompanied by a reduced level of confidence in the effective functioning of formal institutions that previously was 
used as modality that shaped the institutions and social norms and some of them had already well institutionalized. The strong state intervention in the New Order led to the institution losing its function. The revitalization of institution in the village is influenced by non-optimal control of the state during democratic transition. Nevertheless, this informal institution is still linked with other institutions run by religious structure organizations, the bureaucracy of the village and the state apparatus. Agenda of revitalization has been actually initiated since the early 1990s but was not effective. Beginning in the 2000s, informal institutions has been can be run with the maximum and have an important role in social and political change.

The institution revitalized consists of three types: water management, religious activities and social events. All three were able to show the community activities that broke up the dependence degree between elite and grassroots. Villagers recognize communal cooperation as 'gotongroyong' called Soyo in the field of gift of housing assistance. These activities are usually coordinated by the Head of hamlet on top of community's initiative. There is no organizational mechanism and written in the process of assistance because of the type of assistance is determined solely by each person. Coordinator serves only to receive information from interested parties and forward the information to the other resident. Enforcement of Soyo can minimize the gap, primarily in the form of shelter between the citizens who are well-being and poor. In the implementation of this activity, there is someone who serves as a facilitator. Aside from hamlet heads were those belonging to rich can be a pioneer in supplying building materials first.

Other informal institutions are Ro'an, the activities held in the mosque. This activity is relatively free from the political interests and make them a part of organizational mobilization by religious elite to the grassroots. This activity is managed by takmir of mosque which utilize support the mosque congregation to hold religious events. The motives are voluntary and can be done in a mosque belonging to NU, Muhammadiyah or LDII (Interview Sutrisno, 10 January 2007). This type of assistance can vary but is generally in the form of food, drink or other equipment. Community participation determines the success of a religious ceremony. It can also be used as a means of proving one's affiliation to one particular organization.

Informal institutions that used to be managed as part of the village bureaucracy is 'Jogoboyo' which had responsibility for the security system of the village. This position is held by one person where the incentives provided in the form of a crooked land that is narrower than its share of village heads and the equivalent with 'Kebayan' (news giver) and Modin (village moslem leader). In the 1970s the role of Jogoboyo is replaced by Jogotirto because its function was ineffective and almost the entire security system is held by the security forces both the police and the army. At first this office is carried by two people where the incentives are derived from Jogoboyo which is divided by two. Practically, that still works is the distribution and management of water flow from Jogotirto where the task is to set up village irrigation system and drain water from dams or water source nearby to farmers who need them evenly. But hardly perceived significant results of 
work Jogotirto because basically since the 1980s discharges. Position of Jogotirto hardly have any function in the early 1990s, residents formed a set of water users (Himpunan Petani Pemakai Air, HIPA) a formal institution that managed collectively and not related to the bureaucracy and village (Interview Abdullah, 22 December 2006). Although in practice, during the New Order, the government greatly affect its existence.

After state release their influence, HIPA fully operational parts scattered into different in each area. Since 2002, the structure of HIPA has set consists of using farmers in an area called the "group". Above this group there are "sub" which embodies several groups and will coordinate directly to the government irrigation agency which control of the dam. HIPA can work cause support from informal device and characterized namely in the area of the group consists of several "Wangan"segments of irrigation channels among the rice plots-. Usually in one Wangan there is $5-10$ paddy fields coordinated by one person. Coordination among Wangan are done almost every day took place in the middle field, on the sidelines during a break in shacks or under trees. Farmers who need their water discharge was added and they just called coordinator of wangan who will organize it with the sub and they went on the Government Irrigation Agency to request additional water discharge.

Agricultural society processing has been such an important position as part of people's livelihoods. As in other agrarian society, the wage system affecting the fluctuation tendency compliance in relation of clientelism. The wage system is determined by the compliance and willingness of client to serve the interests of patron. The wage system has been established for a long time but suffered distraction at the New Order era where the remuneration is based on the relationship between employer-labor gap. At that time, the wage system depends on the structure of land ownership and agricultural settings and production results. Not all the hamlets have the same amount and composition of the right of agricultural land ownership. But the average can be categorized more sharecroppers or tenant farmers rather than the owner.

In 2001, occurred important changes regarding the level of society needs. Especially after periods of economic downturn in the span of 19961999. The impact is the restructuring of the wage system based on the calculation that more widespread and not just based on employer-worker relations. Farmers who originally have no land wear lease fields. Tenant farmers need to buy the land at a price set at IDR 800.000 per $100 \mathrm{~m} 2 /$ year and the average tenant will request land to $500 \mathrm{~m} 2$. The calculation can be obtained with the maximum benefit. Tenant farmers relative could save crops and invest in other effort such as children's education and to invest in the fisheries sector.

In addition to tenant farmers, there was sharecroppers that set the maru system where peasants are responsible to the needs of fertilizer, seed until maintenance while landowners only providing land. Distribution of profits made from earnings results after cut production costs by 50 percent respectively. There also are implementing a system for which the owners and tenants alike participate in the capital include the provision of seeds, fertilizer and maintenance. After harvest, the number of direct income are divided by two. For residents who do 
not have the capital will work as a laborer with a wide range of systems made by the owner of the land, among others: the workers became custodians of the land during a growing season. He or she shall be responsible to repel pest birds that eat the rice when it started approaching harvest. These workers will be paid after the harvest with the provisions of the amount set by the owners of land and there is no standard wage. As for wages alone time can be calculated daily, monthly or in every harvest season.

Sharecroppers and tenants models become the starting point for distribution of agricultural land which was originally concentrated only become the property of landlords. Sharecroppers and tenants have an important role in generating the new wage system to farm workers. In the wage system which connects between the farmer owners, tenants or tenants with the workers highly dependent on the flow of water in each paddy fields. There are differences between the system implemented in the hamlet of Krecek, Nepen and Sumber Agung which relatively get a smooth flow of water or irrigation channels than in the hamlet of Bumirejo. In that village, the water flow during the dry season is few. Lack of water supply makes the farmers construct wells pump in the middle of rice fields. Until 2005, there are 12 pumps irrigates agricultural land in the dry season only. The well is made by the individual and managed by the respective owners, and it was likely to be exploited by its neighbors. In these conditions, wages give lower because agricultural land owners have to pay the cost of electricity for pumps and fuel. For farm workers, their income could be increased by working to create or repair the embankment because plowing work has been done through a contract system with the tractor machine.
In addition to the remuneration that was given to farm workers, also given to other professions such as water officer regulated based on a percentage of the harvest. Average water officers get $12 \mathrm{Kg}$ of rice per harvest for every field in an area of $250 \mathrm{ru}$. Each block of the fields managed by one person and for area of $250 \mathrm{ru}$ there were a total of five people with one coordinator. They served to drain the water from the stream of Sumbersari in four days a week. While the rest is met from the flow of springs. Coordinator of wangan entitled to a wage of IDR 2,500 for each $100 \mathrm{~m} 2$ irrigated rice fields of small irrigation channels in the Wangan segment. Coordinators are usually incorporated in the HIPA designated in village meetings. To do their task, the water management officers divided into three parts: paddy fields, which served to open a small dam and bringing water from the center of a large dam. Wages that was received by officers IDR 30.000 per pool, for once fill detailed IDR 20.000 , for the purchase of water and IDR 10.000 for fees. As for paddy fields and agricultural crops by IDR 7500 per section (Interview Abdullah, 23 December 2006).

The wage system profession followed by sanctions provisions on violations. Village Forum tasked appointing and dismissing the water coordinator when the relevant dishonest to be replaced with another. For example, selling water flow to block that should not get a turn. Each coordinator is also a reward tailored to the needs of water that desirable, it is not certain amount of payment will be accepted. But the coordinators earn an average of IDR 25.000. Owners of agricultural land an average area of 2 lot or 1 'bau'. But for wealthy farmers, they also have the installation selepan (millers) and average 
has a 15 or 30 parts smell but most have been assigned to his children and grandchildren. Rich farmers get it from the inheritance. For those who have a family farm laborer who work outside the village, could be a tenant farmer with a maximum land area of $100 \mathrm{~m} 2$. They maintain many cows to add their income. From the results worked out, some farm worker families can afford to buy the rice paddies to the category under half of 'bau' or $250 \mathrm{~m} 2$ for IDR 50 million (Interview Heryan, 21 December 2006).

The wage system proves the shift from closed to become open clientelism. This is evident from the pattern adopted in the processing and trading of rice farming. In the purchase of agricultural products, the buyer of rice (Borek) doing the estimated 3 days before harvest (segrek) and in charge begin from rice field to transport to the miller house (Interview Supri, 26 January 2007). The fastest money of purchase can be disbursed one week after three days to negotiate the price. Usually Borek is also the owner of miller house, land-drying, its own employees. Borek employees could loan to another Borek and employees can work all day without waiting for the harvest season. The workers were farm laborers who also owned the cow. These workers earn a lot of profit if they are creative. In addition to participating harvest, then worked in the miller house, they could also take the 'kawul' (twigs rice) free of residual to wear their animal feed ingredients.

\subsection{Network of Pesantren and Elite Reconfiguration}

The first identification can be recognized is how does Pesantren as a major institution in the Santri's community is changing? Until 2005, there were new typologies of Pesantren network. There are three types network comprising: first, -relational network based on the obedience where the influence of the Kiai only applies to Santri and their families. The importance of maintaining relationships due to their obedience have a direct command. Pesantren belonging to the network are the old Pesantren and their Islamic study group in mosque, followed by local resident nearby. Patronage developed also rooted to the family circle of Santri .

The second network is a reciprocal network based on influences which had impact on mobilization in the communities surrounding Pesantren. In addition to differences in the size of the political, the tendency of cultural transformation such as the effectiveness of religious propaganda is also visible. This type of Pesantren refers to a large as Lirboyo in Kediri. The mobilization effectiveness not only among the large families of Santri but extends to the other institutions. Kiai can enter and control of public institutions such as village organizations and other forums outside the religious authority.

The third network is a combination of both types of networks over which paradoxically network-based strategic interests. This network connecting Pesantren with the political forces that close near the knot of the state. Perhaps that has not faded is the pattern of networking between Kiai who increasingly dense and complex that could be called network of Kiai also be a network of Pesantren. Fellow of NU's pesantren for example, not much going rivalry that is not affected by political attraction such support on a particular political party. Kiai and Pesantren network are moving on the basis of genealogical descent or kinship in a large family ties. Most of Kiai who graduated 
from a Pesantren including relatives from outside the area still build synergy in the management and also sharing of information and strategies in dealing with other institutions.

Network type of Pesantren give effect to the elite fragmentation. The influence of religious elite in social and political activity also weakened. Grassroots has the ability to perform open criticism and restrict their social and political role. In great annual event called "Yasinan Akbar " recitation for example, citizens who become participants can directly criticize the middle of talking in front (interview Heryan, 21 December 2006). In the hamlet Nepen, public spaces such as coffee shops and meetings hamlet has become a space argued without being restricted by the dominance of the elite. Establishment of the elite position then undergoes reconfiguration. From hegemonic authority of the religious elite which becomes more pluralistic where political and economic elite also have a major influence.

Democratization create elite domination and control is eroded. Mobility and changes in the structure of elite itself runs very slowly. The weakening of elite control causes the network of political economy which was originally organized and involve by religious social support, mainly derived from state support began disintegrating. The scope of their control no longer embraces all aspects but is limited to their respective bases. Changes in economic structure led to the emergence of new economic actors where networks of the old elite who no longer receive state support, was unable to maintain its strategic position. The main control of the social interaction weakened beforehand because the society has benefited from changing higher structure. This causes the grassrootselite relationship is more equal-relational because each has strengths that can be used as a bargaining tool.

The advent of the revitalization of informal institutions cause the religious elite are no longer able to exploit religious legitimacy basis to sustain its authority in the public sphere. This changes had resulting impact by interlocking with each other including; First, the weakening of the religious elite control of the public institutions at the village level. Thus, the grassroots can take advantage of the original channels they control to enter and be used as a venue for the actualization of the interests of its strategic interest. Interaction with the outside world more openly and enable them to create new networks that allows the interaction of economic, social and politics. In some cases, the level of dependency on local elites can be minimized. The opening of public space is essential for accelerating the empowerment of the grassroots can find the relevance.

Patrimonial system in the Santri's community supported by an elite whose have a role as a backer whose are divided into three bases; the economic elite, the religious elite and the political elite. The economic elites are still dominated by the residents that holds the status of hajj from various organizations. They no longer want to really invest a fortune to prophetic religious purposes. Rather than simply elevate the social status. Methods used are also different, ranging from working hard to accumulate capital, to selling their inherited land or earn money by quickly by working outside. On these changes, of course, has a great influence on social change which associated with mastery of capital and 
production factors. Economic elite came to be dominated by the successful farmer and already go to Hajj and build a network with the religious elite by donating some of their land for the building of worship and school. Collaboration between Hajj being and economic elites and Kiai- as a part of the religious elite- to fruition. Kiai's had benefited from capital support in the pilgrimage donation, upkeep of the mosque, procurement of equipment and logistics organizing Islamic study groups. While every Hajj also enjoyed a good image in the eyes of the public.

The weakening of the political elite control against the grassroots due to the openness of the political space. The response given by the grassroots to political elite in the form of the development of the capacity of political bargaining, freedom to choose an affiliation with personal preference and relatively bold self-determining political choice. In the hamlet of Sumberagung for example, there is a group of farmers who selected the PDIP party because they believe that the parties concerned and representing of small farmers. Although they are members of recitation group (pengajian) and admitted of NU but did not want to follow the endorsement by other religious elite to choose $\mathrm{PKB}$ or PPP. A group of farmers from the village Mulyorejo when following development plan meeting (Musrenbang) have the courage and smoothly inquire about the flow of Village Fund Allocation (ADD). They also dare debate the opinion of elites seemed concerned in order to manage the funds. Formally, the ability of grassroots has raise the bargaining power to the political elite in touch with their economic position when dealing with the economic elite.
Patrimonialism in the Santri's community did not simply vanish indeed but only weakened. Patrimonialism still have an existence where elite supporters still trying to defend itself by building a compromise with the grassroots. Compromise shape has two kinds of bases: First, the economic base in which the economic elite has open their business space for cross-organization and does not make the form of affiliate organizations as an excuse to shut down access to grassroots effort. Second, the cultural basis where the religious elite could accept the implementation of the cultural activities undertaken by abangan group and supported by the bureaucracy of village. They aim to make their position in the village administration become stronger in order to claim and getting support for their effort to preserve the existing tradition. Categorization referring to priyayi groups attached to person who control the land or customary 'yasan' like 'kamituwo' or village apparatus. In the hamlet of Mulyorejo and Bumirejo, activities that inherent in the 'abangan' and 'kejawen' group's still performed with various modifications because most of them are members of NU. They held a puppet, alms food from the earth with buffalo meat and should not be from other animals is a necessity which is maintained until today.

The representation of grassroots to held traditional ceremony is recognized by the village administration. Despite the village government never gave formal provisions that support the existence of these rituals, but most of the hamlet head has a position as a sponsor of the annual series of events. In the event of village ceremony (bersib deso) held at Bumirejo, Mulyorejo, and Pulorejo, head of the hamlet became a coordinator and make the event as 
official activities in hamlet level. As told by the head of the hamlet of Bumirejo which is the brother in law of Haji Abdullah, the leader of the local LDII that: "It is customary of Java that cannot be removed and does not affect to the Islamic worshipers. In fact, the 'mbesob' or dancing are here as well, from various Islamic organizations. In addition, we also present puppets and 'badrab' in the event. The event need cost that is guaranteed by all citizens voluntarily and does not set the amount in ascertain amount "(interview head of Bumirejo Hamlet, 11 January 2007).

How both economic and cultural bases such compromises have an impact on the polarization of the political support to the political parties? Political parties have contributed to the shifting orientation of the grassroots and make them not just as passive sympathizers. They have a high bargaining power due to the opening of public space. Information and network access is also better that allow them to obtain references before political transactions conducted with politicians. Their capacity is also increasingly showing independence in determining its political choices. An adequate reason can be given to provide support for a political party or politician without being influenced by the pressures come from the elite to exploit their economic weakness for political parties. PKB politicians, for example, are more able to prove that by approaching the religious elite, the support of the people can be obtained.

Most of the political elite had made their political parties as a substitute for the flow of support from the state. The religious elites also often use their influence to affect political choices of its members. While the grassroots are not interested directly unless their relation with politicians can be done directly and collectively without intermediaries. Religious elite close to the political parties have a special interest, either pragmatic or ideological. Kiai Zaini Khudori leaning to PKB while Kiai Jawahir inclined towards PPP. But for senior Kiai like Yunus Mubari insists that the political attitudes should be completely accountable. Other religious elite figures such as Kiai Jaiz in Bumirejo, in every election has always been a sponsor of campaign for political parties he followed. At the time Sufism order (tarekat) Qadiriyah Naqsyabandiyah supports Golkar, Jaiz participate garner support for Golkar (interview Jaiz, 22 December 2007).

The political behavior of grassroots is not always the same applies to the selection of the candidate carried by political elite. Rising of MegawatiHasyim during presidential election 2004 apparently was not followed by the political support deserving from Santri's community. This indicates that Indonesian voters more independent and rational in their political behavior and cannot be dictated by political party leaders, religious leaders and others. Azra opinion override rejection factors when saw in the case in Krecek. NU member does not reject Hasyim when advanced to vice president. The religious elite still saw Hasyim as a nice figure but it should not be a vice president for Megawati which led to the rejection appears to be a contradiction of the orientation of the political elite who each perceive inappropriate male under the female. This is had serious impact and switch political choice of many NU members given to Yudhoyono.

In Krecek, PKB get most votes than PPP, Golkar and PDIP. Moreover, concerning the interpretation of the 
1984 NU's khittah, such as Kiai Jawahir already rejected the involvement of $\mathrm{NU}$ and its board to be involved in the carrying-supporting because it can divide the people (interview Jawahir, 10 January 2007). While Kiai Zaini have different opinion, he argue as institutionally NU no longer in politics but some its person are still there and at least this involvement is not to be a problem because it is personal (Interview Zaini Khudori, 20 December 2006). Another Kiai Yunus also have dissenting and saw political involvement by NU is not at the level of practical and pragmatic but consistently fight for its beliefs in influencing policy makers in order to get benefit and goodness (Interview Yunus Mubari, 11 January 2007). Most of other religious elite consider that support for a political party or politician can be done personally and not to confuse the interests of the organization. Those who choose this path tend to be more assertive and be able to account for all the organization's activities to its members. Both kinds of options for the religious elite in the political process make the grassroots increasingly have more reference and it is not easy to accept the invitation from one of the elite figure. The contradiction in the orientation of the elite on the one hand want to promote the education sector and the continuity of religious activity. On the other hands they are hit by the economic choices personally and weak capacity to develop institutions with available resources. But most elite provides a smoothest way to support their politicians, even came from the same organization, or at least coming from circle of Santri. Contradictions concerning on the political choices amongst elite had produces an informal consensus between the elite and members of subordinate institutions.
This consensus is one part of clientelism model but more openly because elite as the patron does not have the absolute binding force to the client and the client can decide in certain circumstances to change their patron.

\section{Conclusion}

This study answering the gap by looking at the dynamics and shifting in Santri's community. Especially in a period of democratic transition in the span of 1998-2007 which became a crucial time to explain how far the shifting level in social structure, economy and culture in rural communities. The changes that occur at the micro level is more influenced by the structural changes that occur at the macro level. But the shifts and changes shape not necessarily be equated with the conditions prevailing at the macro level. The response given by the micro level has a variation in a matter of time, speed, and manifestation. In the case in the Krecek village, shifting political legitimacy is heavily influenced by the weakening of state support to the political elite that functions as a state agency and together with state apparatus had fully control against common resources and socio-political mobilization. The existence of institutions also noteworthy to be observed because of its function in delivering the legitimacy of the elite get various privileges from the state and also from the society. Pesantren must adjust to the changes their relationship with the elite and build new networks with politicians and political parties to get the support material. Their cultural legitimacy is not enough to make the revitalization of social and political role of Kiai and his Pesantren. Structural shifts generate new forms in the relationship between the elite-grassroots 
and increase the capacity and bargaining power of the grassroots against elite and the state. This strength was caused by weak consolidation of the elite to solidify its structural building to keep control of their dominance to economic resources and political network as the agency of the state. Response to structural changes through democratization, and then produce things that surprised. Relationships between elite-grassroots originally contains gap and becomes relatively more tightly. This study also reveals the emergence of patrimonial system in Javanese society was fragmented and more caused by the failure of the elite took over the state position in times of democratic transition. Patrimonial fragmentation is not the end of patrimonialism within the Santri's community. But these forms lead to the dismantling of patrimonialism because of the nature of his power spread in several smaller entities. The deployment was not followed by a tangle of power that pretends to restore authoritarian power as previous New Order era.

\section{Bibliography}

\section{Book and Journal}

Anderson, Benedict R, 1972. Old State New Society: Indonesia New Order in Historical Perspective, Journal of Asian Studies 42, 477-496

Anderson, Benedict R \& Audrey Kahin (ed), 1982, Interpreting Indonesian Politik: thirteen Contributions to the Debate, Ithaca, Cornell University, Southeast Asia Program, Modern Indonesia Project

Archer, M. (1995). Realist Social Theory:

The Morphogenetic Approach.

Cambridge: Cambridge University Press.
Jackson, Karl D, Kewibawaaan Tradisional, Islam dan Pemberontakan: Kasus Darul Islam Jawa Barat, Pustaka Utama Graffiti, Jakarta, 1990

Mulkhan, Abdul Munir, Runtubnya Mitos Politik Santri: Strategi Kebudayan dalam Islam, Sipres, Jogjakarta

Booth, Anne \& Peter McCawley (peny), 1990, Ekonomi Orde Baru, Boediono (terj), Jakarta, LP3ES

Hefner, R.W Islam Pasar Keadilan: Artikulasi Lokal, Kapitalisme dan Demokrasi, Lkis, Yogyakarta, 2000: 39

Jay, Robert R, 1969, Javanese Villager: Social Relations in Rural Modjokuto, Cambridge, Mass, MIT Press

Moedjanto, G, 1986, The Concept of Power in Javanese Culture, Yogyakarta, Gadjah Mada University Press.

Nakamura, Mitsuo, 1983, The Crescent Arises over the Banyan Tree: A Study of the Mubammadiyah Movement in a Central Javanese Town, Yogyakarta, GMU press

Woodward, Mark R, 1999, Islam Jawa: Kesalehan Normatif us Kebatinan, Hairus Salim (terj), Yogyakarta, LkiS.

Gaffar, Afan, 1992, Javanese Voters: Election Under the Hegemonic Party System: A Case Study of Indonesia, Yogyakarta, GMU Press

Geertz, Clifford, 1989, Abangan, Santri, Priyayi dalam Masyarakat Jawa, Aswab Mahasin (teri), Jakarta, Pustaka Jaya.

Varley, Robert C.G, 1993, Masalah dan Kebijakan Irigasi, Munawir (ter), Jakarta, LP3ES 
Geertz, C. (1973). The interpretation of cultures: Selected essays. New York: Basic Books.

Dhofier, Zamakhsyari Tradisi Pesantren: Studi tentang Pandangan Hidup Kiai, LP3ES, Jakarta, 1982.

Ida, Laode Anatomi Konflik: NU, Elit Islam dan Negara, Pustaka Sinar Harapan, 1999.

Bruinessen, Martin van NU: Tradisi, RelasiKuasa, PencarianWacanaBaru, LKiS, Yogyakarta, 1994.

Feillard, Andree NU vis a Vis Negara, LKiS, Yogyakarta, 1999.

Fealy, Greg Ijtihad Politik Ulama: Sejarah NU 1952-1967, LKiS, Yogyakarta, 1998

Scott, James C. (1972). "Patron-Client Politik and Political Change in Southeast Asia." American Political Science Review 66: 1, 91 - 113 (March).

Geertz, Clifford Involusi Pertanian: Proses Perubahan Ekologi di Indonesia, Jakarta, Bhrata Karya Aksara, 1983.

Kurasawa, Aiko Mobilisasi dan Kontrol: Studi tentang Perubahan Sosial di Pedesaan Jawa 1942-45, Gramedia, Jakarta, 1993.

Schiller, Jim "State Formation dan Rural Transformation: Adapting to the New Order in Jepara" dan OlleTornquist, "Notes on the State and Rural Change in Java and India", dalam Arief Budiman (ed) State and Civil Society in Indonesia, Monash Paper on Southeast Asia, 1992.

Leon A Mears dan Sidik Moedjono, KebijaksanaanPangan, dalam Anne
Both dan Peter McCawley, (peny), Ekonomi Orde Baru, LP3ES, Jakarta, 1990,

Mayntz, R. (2004). Governance im modernen Staat. In Governanceregieren in komplexen regelsystemen (pp. 65-76). VS Verlag für Sozialwissenschaften.

Luhmann, N. (1983). Legitimation durch verfahren (Vol. 443). Frankfurt aM: Suhrkamp.

Weber, M. (1978). Economy and society: An outline of interpretive sociology. Univ of California Press.

Turmudi, Endang. Struggling for the Umma: changing leadership roles of kiai in Jombang, East Java. ANU E Press, 2006.

Fox, James J. Currents in contemporary Islam in Indonesia. Research School of Pacific and Asian Studies, Australian National University, 2004

Antlöv, Hans. "Village leaders and the New Order." Leadership on Java: Gentle Hints, Authoritarian Rule. Richmond, Surrey, UK: Curzon Press. Nordic Institute of Asian Studies, Studies in Asian Topics 16 (1994): 73-96.

Helmke, Gretchen, and Steven Levitsky. Informal institutions and democracy: Lessons from Latin America. JHU Press, 2006.

\section{Interview}

Abdullah, Head of LDII Bumirejo, 22/12/2006

Kiai Ahmad Jaiz, Modin of Bumirejo, 22/12/2006 
Haji Heryan, Businessman of Sumberagung, 21/12/2006

Kiai Jawahir, Head of Tarekat Qadiriyah Naqsabandiyah Krecek, Nepen, 10/01/2007

Head of hamlet, Bumirejo, 11/01/2007

Supri, Peasant in Pulorejo, 26/01/2007

Sutrisno, Head of Muhammadiyah, Nepen, 10/01/2007

Kiai Yunus Mubari, NU Krecek, $11 / 01 / 2007$

Kiai Zaini Khudori, Head of NU Krecek, 20/12/2006

Krisbanu, Head of Krecek village $17 / 12 / 2006$

Collective Interview Head of hamlet, Bumirejo, Polorejo dan Nepen, 18/12/2006

\section{Official Document}

Village Monograph (Monograf Desa) tahun 2004, 2005, 2006

Central Statistical Bureau (CBS) (Badan Pusat Statistik) Kabupaten Kediri, 2006

Village archive (Arsip Desa) 